\title{
GENETIC DIVERSITY OF PERENNIAL RYEGRASS WILD ECOTYPES BASED ON AGRO-BIOLOGICAL TRAITS
}

\author{
Gražina Statkevičiūtė*, Vilma Kemešytė*, Nijolè Lemežienè*, Grigorij S. Konik**, \\ and Maria Chomiak ${ }^{* *}$ \\ * Lithuanian Research Centre for Agriculture and Forestry, Institute of Agriculture, \\ Instituto a. 1, Akademija, Kèdainiai distr., LT-58344, LITHUANIA; \\ grazinastat@Izi.It \\ ** Institute of Agriculture of Carpathian region, Ukrainian Academy of Agrarian Sciences, \\ Lishnia, Drogobich distr., Lvov r., UKRAINE; \\ d_stancija@mail.Iviv.ua
}

Communicated by Isaak Rashal

\begin{abstract}
Perennial ryegrasses (Lolium perenne L.) are one of the most valuable forage grasses, characterized by high productivity and good feed quality. Intensive cultivation of ryegrasses has resulted in reduced genetic diversity. Wild ryegrass ecotypes can be used in breeding programmes as parental genotypes with the aim to neutralize this genetic erosion. The objective of this study was to evaluate wild perennial ryegrass ecotypes from Ukraine under Lithuanian climatic conditions. Wild ecotypes were collected in Western and Northern Ukraine in 2008-2009 and planted in 2009-2010 as part of the germplasm collection at the Institute of Agriculture, Lithuanian Research Centre for Agriculture and Forestry. Winter survival, re-growth in spring, plant height, beginning of heading, flag leaf length and width, inflorescence length and biomass were assessed. High variation of traits was detected among ecotypes (CV $=22.64-41.41 \%)$, except for winter survival, for which the coefficient of variation was average (CV $=18.26 \%)$. Principal component analysis was carried out and a dendrogram was computed based on agro-biological traits. In both years of investigation the grouping of ecotypes was mostly influenced by biomass, plant height and date of heading.
\end{abstract}

Key words: perennial ryegrass, genetic diversity, wild ecotypes.

\section{INTRODUCTION}

Perennial ryegrass (Lolium perenne L.) is one of the most important grass species of temperate climates. It is widely cultivated for forage due to high yield, good digestibility and tolerance to grazing pressures and it is used also for amenity purposes (Wilkins, 1991; Humphreys et al., 2010). Perennial ryegrass is a diploid species $(2 n=2 x=14)$ with a two-locus self-incompatibility system, which ensures a high degree of genetic variation in populations. Information on the level and distribution of genetic diversity in crop species is important for the selection of parental materials and optimum strategies of preservation of germplasm in gene banks (Gunter et al. 1996).

Intensive cultivation of ryegrasses for feed has resulted in reduced genetic diversity. In practice, the time of flowering is the most important character for the grouping of germplasm to establish gene pools. Following this approach, breeders have combined both closely related and unrelated materials. This might be one of the reasons for the rather low genetic diversity among perennial ryegrass cultivars
(Roldan-Ruiz et al. 2001). In order to neutralize this genetic erosion, grass breeders can collect their base materials from natural grassland. Wild ecotypes, collected in their natural habitats, usually are not productive, but some genotypes exhibit high resistance to various biotic and abiotic stresses, and therefore they can be used as parental genotypes in ryegrass breeding (Lemežienè and Kanapeckas, 2008).

The usefulness of the germplasm collections depends on sufficient characterisation. Various approaches can be applied to measure diversity of accessions and to classify them. Genetic diversity can be measured using DNA markers (Roldan-Ruiz et al., 2001; Bolaric et al., 2005; McGrath et al., 2007) or traditionally, by evaluating morphological traits (Bennet et al., 2000; Mirjalili et al., 2008; Sartie et al., 2009). Thorough evaluation of various agro-biological traits of foreign ecotypes under local climatic conditions is especially important for breeding programmes. The objective of this study was to evaluate the diversity of wild perennial ryegrass ecotypes from Ukraine under Lithuanian climatic conditions. 


\section{MATERIAL AND METHODS}

Plants of 40 wild ecotypes of perennial ryegrass (Lolium perenne L.), collected in 2009 and 2010 in natural habitats of grasses in North and North West Ukraine (Lviv, Volyn, Rivne and Zhytomyr regions) (Table 1), were planted in 2010 and 2011 as part of the germplasm collection at the Lithuanian Institute of Agriculture. Lithuanian variety 'Žvilge' was used as standard. Plants of each genotype were planted at $50 \times 50 \mathrm{~cm}$ distances. In the autumn of each year, phosphorus and potassium fertilisers $\left(\mathrm{P}_{60} \mathrm{~K}_{90}\right)$ were applied. Nitrogen fertiliser $\left(\mathrm{N}_{150}\right)$ was applied each year of herbage use in several applications: in spring $\mathrm{N}_{60}$, and $\mathrm{N}_{45}$ after the first and second cut.

In the collection trials the following parameters were assessed: winter survival, re-growth in spring, beginning of heading, plant height, length and width of flag leaf, inflorescence length and biomass. The parameters were estimated using the standard UPOV methodology (Anonymous, 2006), where a score of 9 represent very high and 1 is a very low value for the trait.

The spring of 2010 was warm, with sufficient available moisture in the soil. The weather in June was cool. There were days in July-April months when air temperature rose above $30^{\circ} \mathrm{C}$. The entire growing season was characterised by abundant rainfall.

Table 1

COLLECTION SITES OF WILD Lolium perenne ECOTYPES

\begin{tabular}{|c|c|c|c|c|c|}
\hline $\begin{array}{c}\text { Accession } \\
\text { No. }\end{array}$ & $\begin{array}{c}\text { Latitude } \\
\mathrm{N}\end{array}$ & $\begin{array}{c}\text { Longitude } \\
\text { E }\end{array}$ & \begin{tabular}{|} 
Accession \\
No.
\end{tabular} & $\begin{array}{c}\text { Latitude } \\
\text { N }\end{array}$ & $\begin{array}{c}\text { Longitude } \\
\text { E }\end{array}$ \\
\hline 3809 & $49^{\circ} 96^{\prime} 19^{\prime \prime}$ & $24^{\circ} 57^{\prime} 28^{\prime \prime}$ & 3832 & $50^{\circ} 27^{\prime} 99^{\prime \prime}$ & $25^{\circ} 50^{\prime} 69^{\prime \prime}$ \\
\hline 3810 & $49^{\circ} 57^{\prime} 93^{\prime \prime}$ & $24^{\circ} 42^{\prime} 51^{\prime \prime}$ & 3833 & $50^{\circ} 34^{\prime} 07^{\prime \prime}$ & $25^{\circ} 33^{\prime} 84^{\prime \prime}$ \\
\hline 3811 & $49^{\circ} 57^{\prime} 93^{\prime \prime}$ & $24^{\circ} 55^{\prime} 59^{\prime \prime}$ & 3834 & $51^{\circ} 01^{\prime} 70^{\prime \prime \prime}$ & $25^{\circ} 07^{\prime} 25^{\prime \prime \prime}$ \\
\hline 3812 & $49^{\circ} 58^{\prime} 18^{\prime \prime}$ & $24^{\circ} 53^{\prime} 88^{\prime \prime}$ & 3879 & $49^{\circ} 14^{\prime} 92^{\prime \prime}$ & $23^{\circ} 21^{\prime} 04^{\prime \prime}$ \\
\hline 3813 & $50^{\circ} 11^{\prime} 21^{\prime \prime}$ & $25^{\circ} 24^{\prime} 94^{\prime \prime}$ & 3880 & $49^{\circ} 11^{\prime} 93^{\prime \prime}$ & $23^{\circ} 18^{\prime} 38^{\prime \prime}$ \\
\hline 3814 & $50^{\circ} 20^{\prime} 09^{\prime \prime}$ & $25^{\circ} 38^{\prime} 49^{\prime \prime}$ & 3881 & $49^{\circ} 11^{\prime} 933^{\prime \prime}$ & $23^{\circ} 18^{\prime} 38^{\prime \prime}$ \\
\hline 3815 & $50^{\circ} 35^{\prime} 98^{\prime \prime}$ & $26^{\circ} 28^{\prime} 33^{\prime \prime}$ & 3882 & $49^{\circ} 10^{\prime} 79^{\prime \prime}$ & $23^{\circ} 18^{\prime} 02^{\prime \prime}$ \\
\hline 3816 & $50^{\circ} 36^{\prime} 08^{\prime \prime}$ & $26^{\circ} 32^{\prime} 24^{\prime \prime}$ & 3883 & $49^{\circ} 09^{\prime} 42^{\prime \prime}$ & $23^{\circ} 16^{\prime} 11^{\prime \prime}$ \\
\hline 3817 & $50^{\circ} 34^{\prime} 94^{\prime \prime}$ & $26^{\circ} 47^{\prime} 17^{\prime \prime}$ & 3884 & $49^{\circ} 10^{\prime} 03^{\prime \prime}$ & $23^{\circ} 11^{\prime} 73^{\prime \prime}$ \\
\hline 3818 & $50^{\circ} 34^{\prime} 29^{\prime \prime}$ & $27^{\circ} 12^{\prime} 22^{\prime \prime}$ & 3885 & $49^{\circ} 12^{\prime} 09^{\prime \prime}$ & $23^{\circ} 09^{\prime} 49^{\prime \prime}$ \\
\hline 3819 & $50^{\circ} 33^{\prime} 95^{\prime \prime}$ & $27^{\circ} 42^{\prime} 78^{\prime \prime}$ & 3886 & $49^{\circ} 12^{\prime} 08^{\prime \prime}$ & $23^{\circ} 04^{\prime} 79^{\prime \prime}$ \\
\hline 3820 & $50^{\circ} 33^{\prime} 95^{\prime \prime}$ & $27^{\circ} 42^{\prime} 78^{\prime \prime}$ & 3887 & $49^{\circ} 29^{\prime} 35^{\prime \prime}$ & $23^{\circ} 09^{\prime} 35^{\prime \prime}$ \\
\hline 3821 & $50^{\circ} 26^{\prime} 94^{\prime \prime}$ & $28^{\circ} 05^{\prime} 17^{\prime \prime}$ & 3888 & $49^{\circ} 30^{\prime} 01^{\prime \prime}$ & $23^{\circ} 09^{\prime} 33^{\prime \prime}$ \\
\hline 3822 & $50^{\circ} 20^{\prime} 49^{\prime \prime}$ & $28^{\circ} 20^{\prime} 33^{\prime \prime}$ & 3889 & $49^{\circ} 37^{\prime} 43^{\prime \prime}$ & $23^{\circ} 24^{\prime} 95^{\prime \prime}$ \\
\hline 3823 & $50^{\circ} 23^{\prime} 45^{\prime \prime}$ & $28^{\circ} 41^{\prime} 03^{\prime \prime}$ & 3890 & $49^{\circ} 52^{\prime} 25^{\prime \prime}$ & $23^{\circ} 45^{\prime} 78^{\prime \prime}$ \\
\hline 3824 & $50^{\circ} 30^{\prime} 96^{\prime \prime}$ & $28^{\circ} 39^{\prime} 94^{\prime \prime}$ & 3891 & $49^{\circ} 56^{\prime} 23^{\prime \prime}$ & $23^{\circ} 47^{\prime} 72^{\prime \prime}$ \\
\hline 3825 & $50^{\circ} 39^{\prime} 58^{\prime \prime}$ & $28^{\circ} 38^{\prime} 02^{\prime \prime}$ & 3892 & $49^{\circ} 58^{\prime} 52^{\prime \prime}$ & $23^{\circ} 49^{\prime} 27^{\prime \prime}$ \\
\hline 3826 & $50^{\circ} 43^{\prime} 82^{\prime \prime}$ & $28^{\circ} 37^{\prime} 26^{\prime \prime}$ & 3893 & $50^{\circ} 17^{\prime} 96^{\prime \prime}$ & $24^{\circ} 10^{\prime} 76^{\prime \prime}$ \\
\hline 3827 & $50^{\circ} 44^{\prime} 00^{\prime \prime}$ & $28^{\circ} 37^{\prime} 33^{\prime \prime}$ & 3894 & $50^{\circ} 36^{\prime} 89^{\prime \prime}$ & $24^{\circ} 11^{\prime} 29^{\prime \prime}$ \\
\hline 3828 & $50^{\circ} 58^{\prime} 93^{\prime \prime}$ & $28^{\circ} 29^{\prime} 71^{\prime \prime}$ & 3895 & $50^{\circ} 59^{\prime} 82^{\prime \prime}$ & $24^{\circ} 17^{\prime} 39^{\prime \prime}$ \\
\hline 3829 & $50^{\circ} 48^{\prime} 07^{\prime \prime}$ & $27^{\circ} 57^{\prime} 38^{\prime \prime}$ & 3896 & $51^{\circ} 20^{\prime} 06^{\prime \prime}$ & $23^{\circ} 59^{\prime} 85^{\prime \prime}$ \\
\hline 3830 & $50^{\circ} 33^{\prime} 93^{\prime \prime}$ & $26^{\circ} 13^{\prime} 78^{\prime \prime}$ & 3897 & $51^{\circ} 28^{\prime} 29^{\prime \prime}$ & $23^{\circ} 54^{\prime} 69^{\prime \prime}$ \\
\hline 3831 & $50^{\circ} 27^{\prime} 99^{\prime \prime}$ & $25^{\circ} 50^{\prime} 69^{\prime \prime}$ & 3898 & $51^{\circ} 22^{\prime} 11^{\prime \prime}$ & $23^{\circ} 58^{\prime} 46^{\prime \prime}$ \\
\hline
\end{tabular}

The temperature in the spring of 2010 was variable. The summer was very warm and rainy. Mean temperature in summer was $1.7^{\circ} \mathrm{C}$ higher than the long-term mean temperature. Soil moisture was sufficient during the season, except in June.

The coefficient of variation $(\mathrm{CV})$ and standard error $(\mathrm{Sd})$ of agro-biological traits were estimated using computer software STAT adapted by P. Tarakanovas in Visual Basic of Application as a macro programme to run in EXCEL (Tarakanovas and Raudonius, 2003). NTSYSpc v. 2.2 (Exeter Software, Setauket, NY) (Rohlf, 2005) was used to perform principal component analysis (PCA) and compute dendrograms based on Euclidean distances.

\section{RESULTS}

High (22.64-41.41\%) variation of most investigated traits was observed among wild perennial ryegrass ecotypes. An exception was winter survival (CV-18.26\% in 2009 and $17.29 \%$ in 2010). This trait also scored higher (average 8.56 in 2009 and 7.6 in 2010) than other traits. Plant height was the most variable trait in both years of investigation (Table 2).

Principal component analysis was carried out based on agro-biological characteristics. For traits in 2010, the first three principal components (PC) accounted for $58.67 \%$ of the total variation among the 27 studied genotypes (Table $3)$. PC1 accounted for $22.36 \%$ of total variation, which according to eigenvector values, was best explained by beginning of heading and biomass. PC2 accounted for $18.86 \%$ of total variation and was related to winter survival and plant height. PC3 accounted for $17.45 \%$ of total variation and was explained by re-growth in spring and inflorescence length. The ecotypes were grouped according to these measurements. Genotypes No. 3811 and No. 3823 diverged from the rest (Fig. 1). No. 3811 was late-heading, poorly survived winter, exhibited good re-growth in spring but was very low-yielding, while No. 3823 scored highest in the first three traits and produced average biomass yield. Genotypes No. 3816, 3820, 3822, 3825 and 3828 formed a distinct group in the dendrogram. All genotypes were characterised by good winter survival, tall plants and high biomass yield.

Table 2

AGRO-BIOLOGICAL TRAITS (POINTS) OF PERENNIAL RYEGRASS WILD ECOTYPES, 2010-2011

\begin{tabular}{l|c|c|cc}
\hline \multirow{2}{*}{ Characteristics } & \multicolumn{2}{|c|}{2010} & \multicolumn{2}{c}{2011} \\
\cline { 2 - 5 } & $\bar{x} \pm \mathrm{Sd}$ & $\mathrm{CV}, \%$ & $\bar{x} \pm \mathrm{Sd}$ & $\mathrm{CV}, \%$ \\
\hline Winter survival & $8.56 \pm 1.55$ & 18.15 & $7.60 \pm 1.31$ & 17.29 \\
Re-growth in spring & $6.48 \pm 1.53$ & 23.58 & $6.10 \pm 1.37$ & 22.50 \\
Beginning of heading & $6.33 \pm 1.57$ & 24.77 & $5.05 \pm 1.19$ & 23.58 \\
Plant height & $5.33 \pm 2.34$ & 43.84 & $5.50 \pm 2.04$ & 37.07 \\
Length of flag leaf & $5.37 \pm 2.00$ & 37.29 & $5.70 \pm 1.17$ & 20.60 \\
Width of flag leaf & $5.89 \pm 1.01$ & 17.20 & $4.20 \pm 1.20$ & 28.49 \\
Inflorescence length & $5.37 \pm 1.24$ & 23.18 & $5.00 \pm 1.45$ & 29.02 \\
Biomass & $6.04 \pm 1.79$ & 29.59 & $5.30 \pm 1.49$ & 28.12
\end{tabular}


BASIC STATISTICS OF PRINCIPAL COMPONENT ANALYSIS FOR AGRO-BIOLOGICAL TRAITS OF WILD ECOTYPES, $2010^{1}$

\begin{tabular}{lcccc}
\hline \multirow{2}{*}{ Traits } & \multicolumn{3}{c}{ Eigenvector } \\
\cline { 2 - 4 } & PC1 & PC2 & PC3 \\
\hline Winter survival & 0.211 & 0.737 & 0.208 \\
Re-growth in spring & 0.455 & -0.087 & -0.504 \\
Beginning of heading & 0.693 & -0.278 & 0.008 \\
Plant height & 0.131 & 0.695 & -0.404 \\
Length of flag leaf & 0.337 & -0.139 & 0.180 \\
Width of flag leaf & -0.433 & 0.373 & -0.400 \\
Inflorescence length & 0.565 & -0.181 & -0.450 \\
Biomass & 0.648 & 0.456 & 0.391 \\
& Components & & \\
Eigenvalue & 1.79 & 1.51 & 1.40 \\
\% of variation explained & 22.36 & 18.86 & 17.45 \\
Cumulative variance & 22.36 & 41.22 & 58.67
\end{tabular}

${ }^{1}$ PCA loading are given for plant traits

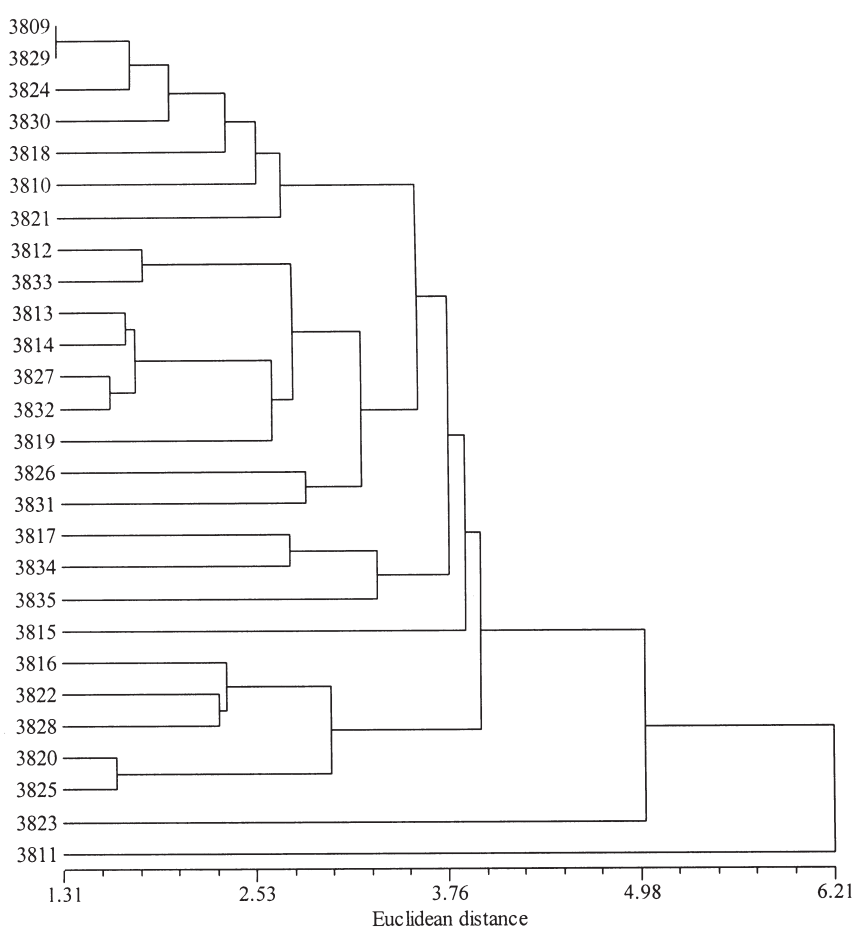

Fig. 1. Dendrogram of wild ecotypes based on agro-biological traits, 2010

In 2011, the first three PCs accounted for $69.83 \%$ of the total variation (Table 4). PC1 explained $38.17 \%$ of total variation and was related to biomass and beginning of heading. Factors explaining PC2 (16.95\% of total variation) were plant height and width of flag leaf. PC3 accounted for $14.71 \%$ of total variation; factors associated with this axis were length of flag leaf and winter survival. Genotypes No. 3887 and 3886 formed a distinct group in the dendrogram (Fig. 2). Both started heading earlier than all other genotypes, had short and narrow flag leaves Genotype No. 3887 was tall and high-yielding, while No. 3886 was short and low-yielding.
BASIC STATISTICS OF PRINCIPAL COMPONENT ANALYSIS FOR AGRO-BIOLOGICAL TRAITS OF WILD ECOTYPES, $2011^{1}$

\begin{tabular}{l|c|c|c}
\hline \multicolumn{1}{c}{ Traits } & \multicolumn{3}{c}{ Eigenvector } \\
\cline { 2 - 4 } & PC1 & PC2 & PC3 \\
\hline Winter survival & 0.464 & 0.092 & 0.738 \\
Re-growth in spring & 0.851 & 0.235 & 0.115 \\
Beginning of heading & 0.891 & 0.004 & -0.056 \\
Plant height & -0.105 & -0.677 & -0.083 \\
Length of flag leaf & 0.443 & 0.168 & -0.765 \\
Width of flag leaf & 0.366 & -0.646 & -0.079 \\
Inflorescence length & 0.391 & -0.616 & 0.106 \\
Biomass & 0.909 & 0.094 & -0.080 \\
Eigenvalue & Components & & \\
\% of variation explained & 38.17 & 1.36 & 1.18 \\
Cumulative variance & 38.17 & 55.12 & 69.83
\end{tabular}

${ }^{1}$ PCA loading are given for plant traits

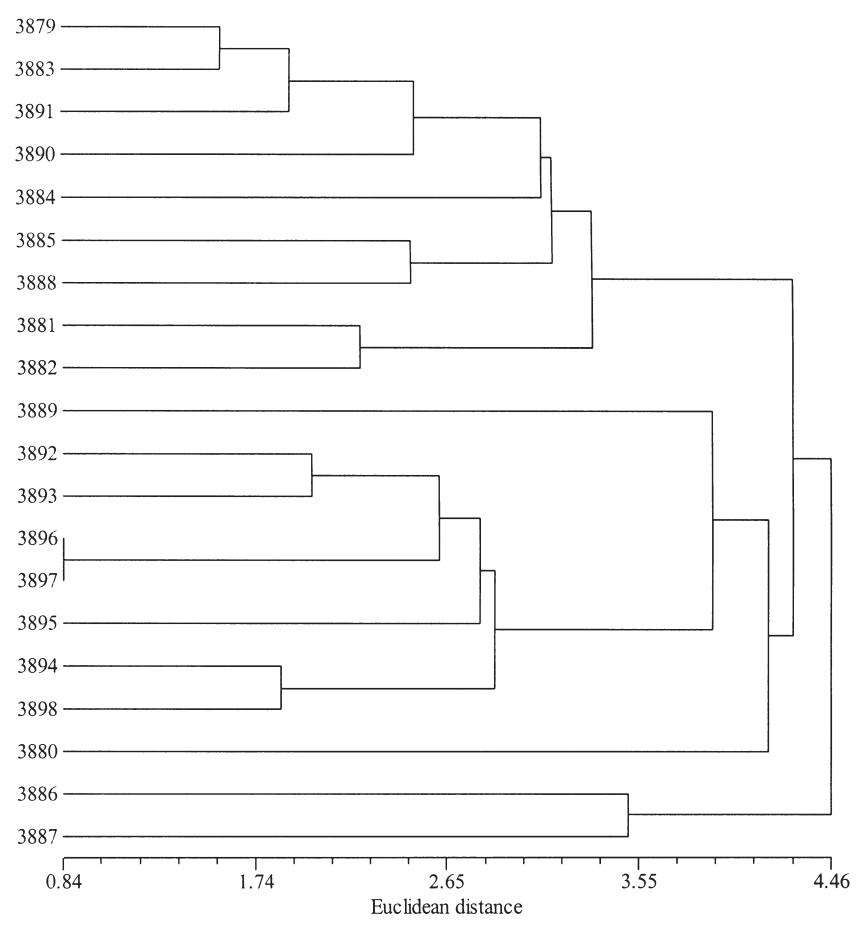

Fig. 2. Dendrogram of wild ecotypes based on agro-biological traits, 2011

\section{DISCUSSION}

High genetic diversity exists in populations of Lolium perenne, due to its self-incompatible nature. Even plants of cultivated varieties are not uniform, let alone wild ecotypes (Ghariani et al., 2003; Bolaric et al., 2005; McGrath et al., 2007). High variation of agro-biological traits of wild ecotypes from Ukraine was confirmed in this study. Perennial ryegrass has been grown in Lithuania for a long time. It is valued for high productivity and good forage quality (Kanapeckas et al., 1999; Aavola et al., 2003). One of the most restrictive factors to wider usage of perennial ryegrasses is 
relatively poor winter survival under Lithuanian climatic conditions. Ukraine is situated to the South of Lithuania, yet most of wild ecotypes used in this study exhibited good winter survival. Winter-hardy genotypes of Ukrainian origin have been identified in previous studies as well (Kemešyte et al., 2010). Biomass yield, another crucial trait, varied markedly among ecotypes. Both tall, high yielding genotypes, suitable for forage and small, narrow-leaved and low yielding genotypes suitable for turf grass breeding were identified.

Various studies of genetic diversity based on phenotypic traits within Lolium perenne species and within genus Lolium identified different traits to be discriminatory factors in principal component analysis. Leaf type and length, spikelet length and width were found to explain principal components in a phenetic analysis of the genus Lolium (Mirjalili et al., 2008). In another study, ear emergence, spike height and flag leaf length and width were the main factors that expalined variation in four species of the genus Lolium (Bennet et al., 2000). Total tiller number and leaf lamina width discriminated two perennial ryegrass cultivars, whereas leaf length and leaf elongation rate identified individual plants within cultivars in PCA (Sartie et al., 2009). Various traits were found to be discriminatory in this study, yet biomass, begining of heading and plant height had the major role.

In general, high phenotypic diversity within wild ecotypes and their suitability for different breeding purposes was confirmed in this study. Both forage type and turfgrass type winter-hardy genotypes could be identified in the relatively small collection.

\section{ACKNOWLEDGEMENTS}

The paper presents research findings, which have been obtained within the long-term research programme "Genetics and purposeful change of genotypes of agricultural and forest plants" implemented by Lithuanian Research Centre for Agriculture and Forestry. Wild ecotype collection expenditures were covered through the Lithuanian - Ukrainian bilateral research cooperation programme.

\section{REFERENCES}

Aavola, R., Van Loo, E. N., Boucoiran, C. F. (2003). Forage quality improvement in perennial ryegrass offspring relative to their genetically distant parents. Chech. J. Genet. Plant., 39, 91-94.
Anonymous (2006). UPOV - International union for the protection of new varieties of plants. Guidelines for the conduct of tests for distinctness, uniformity and stability. Ryegrass, 1, $26 \mathrm{pp}$.

Bennet, S. J., Hayward, M. D., Marshall, D. F. (2000). Morphological differentiation in four species of the genus Lolium. Genet. Resour. Crop Ev., 47, $247-255$.

Bolaric, S., Barth, S., Melchinger, A. E., Posselt, U. K. (2005). Molecular genetic diversity within and among German ecotypes in comparison to European perennial ryegrass cultivars. Plant Breed., 124, 257-262.

Ghariani, S., Trifi-Farah, N., Chakroun, M., Marghali, S., Marrakchi, M. (2003). Genetic diversity in Tunisian perennial ryegrass revealed by ISSR markers. Genet. Resour. Crop Ev., 50 (8), 809-815.

Gunter, L. E., Tuskan, G. A., Wullschleger, S. D. (1996). Diversity among populations of switchgrass based on RAPD markers. Crop Sci., 36, 1017-1022.

Humphreys, M., Feuerstein, U., Vandewalle, M., Baert, J. (2010). Ryegrasses. In: Boller, B., Posselt, U., Veronesi, F. (eds.). Fodder crops and amenity grasses (pp. 211 - 260). Springer Science+Business Media.

Kanapeckas, J., Lemežienè, N., Tarakanovas, P. (1999). Yield comparison of perennial grasses at the heading stage. Žemès Ükio Mokslai, 1, 10-16 (in Lithuanian).

Kemešytė, V., Lemežienè, N., Kanapeckas, J., Vilčinskas, E., BaistrukGlodan, L.Z., Ivanciv, R. (2010). Evaluation of Lolium perenne L. wild ecotypes of Ukrainian origin in Lithuania. Agron. Res., 8, 615-624.

Lemežienė, N., Kanapeckas, J. (2008). Efficiency of wild ecotypes selection for forage and turf grass breeding. Biologija, 54 (2), 125-128.

McGrath, S., Hodkinson, T. R., Barth, S. (2007). Extremely high cytoplasmic diversity in natural and breeding populations of Lolium (Poaceae). Heredity, 99, 531-544.

Mirjalili, S. A., Bennet, S. J., Poorazizi, E. (2008). A phenetic analysis on the genus Lolium (Poaceae) in Iran. Plant Syst. Evol., 274, 203-208.

Rohf, F.J. (2005). NTSYS-pc: Numerical taxonomy and multivariate analysis system, version 2.2. Exeter Software, Setauket.

Roldan-Ruiz, I., van Eeuwijk, F. A., Gilliland, T. J., Dubreuil, P., Dillmann, C., Lallemand, J., De Loose, M., Baril, C. P. (2001). A comparative study of molecular and morphological methods of describing relationships between perennial ryegrass (Lolium perenne L.) varieties. Theor. Appl. Genet., 103, 1138-1150.

Sartie, A. M., Easton, H. S., Matthew, C. (2009). Plant morphology differences in two perennial ryegrass cultivars. New Zeal. J. Agr. Res., 52, 391-398.

Tarakanovas, P., Raudonius, S. (2003). Analysis of agronomical research data using computer software ANOVA, STAT, SPLIT-PLOT from package SELEKCIJA and IRISTAT. 58 pp. (in Lithuanian).

Wilkins, P. W. (1991). Breeding perennial ryegrass for agriculture. Euphytica, 52, 201-214.

Received 1 June 2012

\section{DAUDZGADĪGĀS AIRENES SAVVALAAS EKOTIPU G̦ENĒTISKĀ DAUDZVEIDĪBA, PAMATOJOTIES UZ AGRONOMISKO UN BIOLOĞISKO PAZĪMJU ANALĪZI}

Raksturoti 40 Ukrainas daudzgadīgās airenes ekotipi, audzējot tos Lietuvā. Parādīta augsta svarīgo pazīmju mainība, kas norāda uz to, ka pētītais materiāls var būt vērtīgs jaunu šḳirṇu veidošanas izejmateriāls. 